\title{
THE IMPACT OF DONOR ORGAN QUALITY ON THE OUTCOME OF A DECEASED DONOR KIDNEY TRANSPLANTATION
}

\section{UTICAJ KVALITETA ORGANA NA ISHOD KADAVERIČNE TRANSPLANTACIJE BUBREGA}

\author{
Mirjana Laušević',', Milica Kravljača', Marija Milinković', Voin Brković,',2, Svetlana Jovičić Pavlović', Radomir Naumović,',
}

\begin{abstract}
Summary
Increasing disparity between the limited supply of deceased donor organs and the rising demand for kidneys has led to considering alternative strategies for expanding the availability of organs for transplantation.

The first definition of expanded criteria donor contained four different donor risk factors for graft failure: age, history of hypertension, cerebrovascular accident as a cause of death and final pre-procurement creatinine $>133 \mu \mathrm{mol} / \mathrm{l}$. Marginal donors are also those with diabetes or those with anatomical abnormalities.

Other factors such as donor maintenance, surgeon related factors, perfusion and transportation of organs also have an influence on donor organ

The survival benefits seen in recipients of marginal kidney transplants are inferior compared to those in recipients of standard criteria donor kidneys, but significantly better than in those remaining on kidney waiting list.
\end{abstract} quality.

Key words: kidney transplantation, expanded criteria donor, outcome.

\section{Sažetak}

Narastajući disparitet broja raspoloživih i potrebnih organa za transplantaciju podstakao je razmatranje alternativnih strategija za povećanje dostupnosti organa za transplantaciju.

Prva definicija marginalnog donora obuhvatila je četiri faktora rizika za insuficijenciju alografta bubrega: starost, podatak o prethodnoj hiperten-

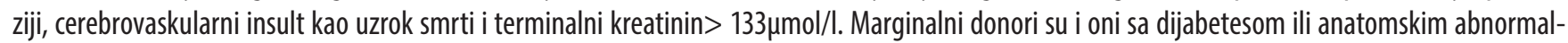
nostima bubrega.

Na kvalitet organa utiču i faktori koji se odnose na održavanje donora, hiruški faktori, način perfuzije i transporta organa.

U odnosu na primaoce organa standardnog kvaliteta, primaoci organa marginalnih donora imaju kraće preživljavanje, ali je njihovo preživljavanje bolje u poređenju sa preživljavanjem bolesnika koji ostaju na listi čekanja za transplantaciju bubrega.

Ključne reči: transplantacija bubrega, marginalni donor, ishod

\section{UvoD}

Potreba za prevazilaženjem narastajućeg dispariteta između broja potrebnih i raspoloživih organa za transplantaciju je kao jedno od mogućih rešenja podstakla korišćenje organa suboptimalnih donora, kao što su stariji donori, donori sa komorbiditetima poput hipertenzije i dijabetesa ili donora sa povišenom koncentracijom serumskog kreatinina u vreme eksplantacije.

U današnje vreme definicija subotimalnog donora nije jedinstvena. U praksi takođe nema jedinstvenog stava za prihvatanje ili odbacivanje organa marginalnih donora, pa jedni transplantacioni centri prihvataju organe koje drugi centri proglašavaju neprihvatljivim.
KLINIČKA PROCENA KVALITETA ORGANA

Prvu definiciju donora bubrega na osnovu proširenih kriterijuma („expanded criteria donors“- ECD) su predložili eksperti Nacionalne mreže za razmenu organa Sjedinjenih Američkih Država („United Network for Organ Sharing"- UNOS) 2001. godine. Ova definicija je izvedena na osnovu 4 faktora rizika lošijeg preživljavanja alografta bubrega kao što su starost donora, podatak o prethodnoj hipertenziji, cerebrovaskularni insult kao uzrok smrti i povišen terminalni kreatinin, odnosno kreatinin u vreme eksplantacije (7). Marginalni donor je definisan kao onaj čiji organi imaju najmanje 1,7 puta veći relativni rizik gubitka funkcije na osnovu prisustva pomenutih faktora rizika u odnosu na organe donora standardnog kvaliteta. Standardni kvalitet donora podrazumeva starost donora izmedju 10-39 godina, bez podatka o hipertenziji, da uzrok smrti nije cerebrovaskularni insult i da je terminalni kreatinin u referentnom 
opsegu (9). Prema ovoj definiciji, svi donori staiji od 60 godina i oni uzrasta od 50-59 godina sa najmanje dva od preostala tri faktora rizika su zadovoljavali kriterijume marginalnog donora. U slučaju transplantacije organa od ECD donora, ne samo da je slabije preživljavanje alografta, već su učestalije i druge komplikacije, kao što je odložena funkcija grafta („Delayed graft function“- DGF). Međutim, preživljavanje bolesnika kojima su presađeni organi od ECD donora se ne razlikuje značajno u odnosu na primaoce organa standardnog kvaliteta, a duže je u odnosu na preživljavanje bolesnika koji ostaju na listi čekanja za transplantaciju (13). Zbog toga se smatra da je ishod transplantacije bubrega od marginalnih donora prihvatliiv, uz uslov da se sprovede adekvatan izbor primaoca i da se svi postupci od održavanja potencijalnog donora do implantacije organa optimizuju (23).

Posle masovnijeg korišćenja organa ECD donora u praksi, nastao je veći broj dopunjenih i preciznijih definicija. Stratifikovan Nybergov skor donora umesto 4, uzima u obzir 7 parametara koji podrazumevaju osobine donora i postupka transplantacije kao što su starost, podatak o hipertenziji i dijabetesu, uzrok smrti, terminalni kreatinin, vreme hladne ishemije (CIT) i promene na arterijama bubrega (12). Stratifikacija podrazumeva klasifikaciju organa na 4 kategorije kvaliteta ( A, B, C, D) prema ukupnom broju bodova koji su dodeljeni na osnovu 7 prethodno pomenutih parametara. Transplantacija organa kategorije $\mathrm{D}$ praćena je najvećom učestalošću DGF, dužim trajanjem hospitalizacije, većom cenom lečenja i slabijom funkcijom alografta u prvih 30 dana posle transplantacije. Ista grupa autora je u cilju jednostavnije implementacije skora, a na osnovu analize podataka iz baze UNOS-a, naknadno smanjila broj faktora rizika koji ulaze u ukupnu vrednost skora na 5 najznačajnijih, u koje se ubrajaju starost donora, podatak o hipertenziji, uzrok smrti, terminalni kreatinin i HLA podudarnost (11).

Implementacija koncepta marginalnog donora u praksi je povećala broj transplantacija, ali nedovoljno da se obezbedi dovoljan broj organa za sve bolesnike na listama čekanja. Jedno od važnih pitanja koje je pratilo korišćenje ovakvih organa je izbor primaoca. U početku, dodela organa marginalnih donora je podrazumevala volju primaoca da ih prihvate, ali i njihovo pravo da budu informisani o proceni stepena funkcionalnosti i dugovečnosti organa koji prihvataju. Primaoci kojima su dodeljeni organi marginalnih donora u većem procentu su bili stariji od 50 godina u odnosu na primaoce organa standardnih donora (9). Pessione skor je po prvi put ukazao da rizik gubitka grafta zavisi od osobina donora i primaoca i definisao ga na osnovu kombinacije osobina donora (hipertenzija, cerebrovaskularni insult, povišen terminalni kreatinin) i starosti primaoca (14).
Novina koja je uvedena sa definisanjem Indeksa rizika donora („Donor Risk Index“- DRI) je stratifikacija verovatnoće dvogodišnjeg poluživota grafta u 5 grupa na osnovu 7 parametara od kojih su neki osobine donora (rasa, hipertenzija, dijabetes, cerebrovaskularni insult), postupka transplantacije (hladna ishemija) ili odnosa izmedju donora i primaoca (HLA podudarnost, podudarnost citomegalovirusnog statusa donora i primaoca) (20). Organospecifični indeks rizika donora („Kidney Donor Risk Index“- KDRI) procenjuje rizik gubitka funkcije alografta bubrega na osnovu brojnih osobina donora i postupka transplantacije, kao što su starost donora, rasa, podatak o hipertenziji i dijabetesu, serumski kreatinin, cerebrovaskularni insult kao uzrok smrti donora, visina, težina, srčani zastoj, hepatitis C, HLA podudarnost na B i DR lokusu, CIT i dvostruka implantacija (16). Ovaj indeks odražava relativni rizik gubitka alografta bubrega u poređenju sa idealnim alograftom koji potiče od donora starosti 40 godina i bez prisutnih komorbiditeta.

Indeks profila donora bubrega („Kidney Donor Profile Index“- KDPI) poredi relativni rizik za nastanak insuficijencije alografta određenog donora sa alograftom koji potiče od prosečnog donora eksplantiranog tokom godine koja prethodi transplantaciji, a na osnovu starosti, težine, visine, rase, podatka o hipertenziji, dijabetesu i njihovom trajanju, uzroku smrti, serumskom kreatininu i prisustvu antitela na hepatitis C virus (3). Ovaj bodovni sistem se aktuelno koristi u sistemu raspodele organa u Sjedinjenim Američkim Državama, gde se najkvalitetniji bubrezi (KDPI <20\%) dodeljuju primaocima sa najdužim procenjenim posttransplantacionim preživljavanjem.

\section{PATOHISTOLOŠKA PROCENA KVALITETA ORGANA}

Krajem devedesetih godina pojavljuju se i patohistološki bodovni sistemi za analizu tkiva bubrega uzetog tokom eksplantacije, sa ciljem detaljnije evaluacije bubrega uzetih prvenstveno od starijih donora. Patohistološka analiza tkiva bubrega u vreme eksplantacije je prepoznata kao procedura koja nudi mogućnost donošenja odluka da li organ iskoristiti za transplantaciju ili odbaciti, ako se bubrezi prihvate da li uraditi jednostruku ili dvostruku implantaciju, kakvom primaocu ga implantirati, ali i u cilju dobijanja referentnog materijala za poređenje tokom kasnijih biopsija.

Za sve patohistološke bodovne sisteme zajedničko je da procenu zasnivaju na procentu sklerotičnih glomerula, stepenu hroničnih promena tubulointersticijuma i hroničnih promena na krvnim sudovima. Remuzzi-jev skor se izračunava na osnovu izraženosti glomerulske skleroze, tubulske atrofije, intersticijalne fibroze i promena krvnih sudova bubrega. Ukupna vrednost skora 1, 2 i 3 dalji postupak usmerava u pravcu implantacije jednog bubrega jednom primaocu, vredmost skora 4, $5 \mathrm{i}$ 
6 upućuje na implantaciju oba bubrega istog donora jednom primaocu, a vrednosti 7-12 ukazuju na potrebu da se organ ne prihvati za transplantaciju (17). U patohistološke skorove ubraja se i Karpinski skor, koji za razliku od prethodnog veći značaj pridaje promenama krvnih sudova bubrega u odnosu na ostale promene, zbog njihovog dokazanog uticaja na veću učestalost DGF i slabije jednogodiošnje preživljavanje alokalema bubrega (5).

Kliničko-patohistološki bodovni sistemi za procenu kvaliteta bubrega donora nastali su na osnovu rezultata koji sugerišu da na jednogodišnju funkciju alografta najveći uticaj imaju kombinacija hipertenzije donora, terminalnog kreatinina $\geq 150 \mu \mathrm{mol} / \mathrm{l}$ i glomeruloskleroze (1).

Ideja ovih bodovnih sistema je bila da se popravi selekcija bubrega na osnovu podataka dostupnih u vreme eksplantacije, ali i da se unapredi selekcija primaoca u cilju boljeg uklapanja osobina donora i primaoca.

Nedostatak svih prethodno pomenutih bodovnih sistema je što ne uzimaju u obzir uticaj oštećenja organa tokom moždane smrti na kvalitet organa i njihovo dugogodišnje preživljavanje (10). Uticaj nepovoljnih efekata moždane smrti na kvalitet marginalnih organa je potencijalno veći, pa je mogućnost njihovog umanjenja posebno značajna u podgrupi ECD donora.

\section{UTICAJ MOŽDANE SMRTI DONORA NA KVALITET} ORGANA

Moždana smrt predstavlja ekstenzivno i ireverzibilno oštećenje centralnog nervnog sistema zbog traume, cerebrovaskularnog insulta ili anoksije, koje ima brojne patofiziološke posledice na organe donora, a najznačajniji su hemodinamski poremećaji i hormonski disbalans. Hemodinamka nestabilnost se javlja kod skoro $90 \%$ donora, a oko $40 \%$ donora je hipotenzivno i uprkos primeni visokih doza inotropa (15). Hipotenzija donora duža od 3 časa povećava rizik akutnih odbacivanja (AO), a izaziva i izraženiju ishemiju organa (18). Hormonske promene koje se javljaju tokom moždane smrti podrazumevaju oslobađanje kateholamina, što zbog periferne vazokonstrikcije doprinosi ishemiji organa. Zbog disfunkcije prednjeg i zadnjeg režnja hipofize, kod oko $80 \%$ donora se javlja insipidni diajbetes, a snižena je i sekrecija tireoidnih hormona i kortizola, što se negativno odražava na kvalitet organa.

Moždana smrt ne izaziva samo ishemiju, već i inflamaciju organa donora, koja utiče na njihovu imunogenost posle transplantacije. U bubregu kadaveričnih donora se u većoj meri eksprimiraju adhezivni molekuli i HLADR molekuli (21). Organi donora sa većom ekspresijom aloantigena posle transplantacije indukuju češće epizode AO.
Moždana smrt izaziva i nespecifičnu inflamaciju koja participira u oštećenju organa posle transplantacije. Inflamacija se povećava sa trajanjem moždane smrti i izraženija je u slučaju hemodinamske nestabilnosti donora (25). Zbog nespesifičnih inflamatornih promena alografta tokom moždane smrti, posle transplantacije se brže razvijaju glomeruloskleroza i intersticijalna fibroza, što je u osnovi hronične nefropatije alokalema (HNA).

Oštećenja organa koja se javljaju tokom moždane smrti su najvećim delom klinički neprepoznatljiva. Manifestno akutno bubrežno oštećenje sa porastom serumskog kreatinina se javlja kod 10-15\% moždano mrtvih donora, što je značajno manje u odnosu na istu pojavu kod ostalih bolesnika u jedinicama intenzivnog lečenja (22). Povišen terminalni kreatinin utiče na veću učestalost ranih komplikacija, kao što je DGF, ali je bez uticaja na dugoročno preživljavanje alografta (24)

Među uzrocima moždane smrti najnepovoljniji uticaj na ishod transplantacije ima cerebrovaskularni insult. Ukoliko je uzrok moždane smrti traumatski, ređe se javlja DGF, uspostavlja se bolja funkcije grafta posle prvog posttransplantacionog meseca i bolje je njegovo dugoročno preživljavanje (8).

\section{UTICAJ TERAPIJE DONORA NA KVALITET ORGANA}

Pre dijagnoze moždane smrti, terapijski postupci imaju za cilj da povećaju šansu preživljavanja bolesnika. Posle moždane smrti, terapiju je potrebno usmeriti ka postizanju što boljeg kvaliteta organa koji se potencijalno mogu transplantirati.

Primena dopamina kod donora ima povoljne efekte na ishod transplantacije bubrega. Mehanizam protektivnog dejstva dopamina na bubreg ogleda se u popravljanju hemodinamike donora i umanjenju ishemičnih promena tokom moždane smrti i kasnije tokom prezervacije organa. Povećanjem hemodinamske stabilnosti donora, dopamin utiče na manju učestalost DGF, što je praćeno manjom potrebom za posttransplantacionim hemodijalizama (19). Zahvaljujući strukturi svog molekula koji sadrži dihidroksi-fenolni prsten, dopamin deluje i direktno protektivno na ćelijsku membranu tubulocita, pa je tubulska nekroza koja nastaje kao posledica ishemije manje izražena. Pozitivan uticaj dopamina je izraženiji u slučaju transplantacija izvršenih posle duže hladne ishemje (6). Primena dopamina kod donora tokom moždane smrti smanjuje i inflamatorne promene u bubregu i time pozitivno utiče na ranu funkciju alografta (2).

Hormonska terapija tokom održavanja potencijalnih donora podrazumeva primenu kortikosteroida, tireoidnih hormona, antidiuretskog hormona i insulina, poje- 
dinačno ili u kombinaciji. Primena metil-prednizolona 3 sata pre eksplantacije, bez obzira na vreme nastanka moždane smrti, suprimira inflamaciju u tkivu bubrega (4).

\section{ZAKLJUČAK}

$\mathrm{Na}$ kvalitet organa za transplantaciju utiče veliki broj faktora. Za razliku od nepromenljivih faktora kao što su starost donora, komorbiditeti i uzrok smrti, koji su sve prisutniji kod donora, zbog težnje da se obezbedi veći broj organa, adekvatnim terapijskim pristupom tokom održavanja donora se umanjuju potencijalna ošetećenja i utiče na bolji ishod transplantacije bubrega. Procena dugovečnosti alografta bubrega pre transplantacije je pretpostavka optimalnog izbora primaoca u cilju racionalnog korišćenja organa dostupnih za transplantaciju.

\section{NAPOMENA}

Rad je usmeno izložen na mini simpozijumu organizovanom povodom 40 godina transplantacije bubrega u Kliničkom centru Srbije na 44. simpozijumu Stremljenja i novine u medicini, Medicinski fakultet u Beogradu, 09.12.2015. godine.

\section{Literatura}

1. Anglicheau D, Loupy A, Lefaucheur C, et al. A simpleclinico-histopathological composite scoring system is highly predictive of graft outcomes in marginal donors. American Journal of Transplantation 2008; 8(11):2325-2334

2. Hoeger S, Reisenbuechler A, Gottmann U, et al. Donor dopamine treatment in brain dead rats is associated with an improvement in renal function early after transplantation and a reduction in renal inflammation. Transpl Int. 2008;21(11):1072-1080

3. Israni AK, Salkowski N, Gustafson S, et al. New National Allocation Policy for Deceased Donor Kidneys in the United States and Possible Effect on Patient Outcomes. J Am Soc Nephrol. 2014;25(8):1842-1848

4. Kainz A, Wilflingseder J, Mitterbauer C, et al Steroid pretreatment of organ donors to prevent postischemic renal allograft failure: a randomized, controlled trial. Ann Intern Med 2010;153(4):222-230.

5. Karpinski J, Lajoie, G, Cattran, D, et al. Outcome of kidneytransplantation from high-risk donors is determined by both structure and function. Transplantation 1999; 67(8): 1162-1167

6. Liu Z, Hoeger S, Schnuelle P, et al. Donor dopamine pretreatment inhibits tubulitis in renal allografts subjected to prolonged cold preservation. Transplantation. 2007;83(3):297-303

7. Mandal AK, Kalligonis AN, Ratner LE. Expanded criteria donors: attempts to increase the renal transplant donor pool. Adv Ren Replace Ther 2000; 7(2): 117 - 130.

8. Marconi L, Moreira P, Parada B, Bastos C, Roseiro A, Mota A. Donor cause of brain death in renal transplantation: a predictive factor for graft function? Transplant Proc. 2011;43(1):74-76

9. Metzger RA, Delmonico FL, Feng S, Port FK, Wynn JJ, Merion RM. Expanded criteria donors for kidney transplantation. Am J Transplant. 2003; 3(4):114-125

10. Novitzky D. Detrimental effects of brain death on the potential organ donor. Transplant Proc. 1997;29(8):3770-3772

11. Nyberg SL, Matas AJ, Kremers WK, et al. Improved scoring system to assess adult donors for cadaver renal transplantation. American J Transplant. 2003;3(6):715-721

12. Nyberg SL, Matas AJ, Rogers M, et al. Donor scoring system for cadaveric renal transplantation. Am J Transplant 2001;1(2):162-170

13. Ojo AO, Hanson JA, Meier-Kriesche HU, et al. Survival in recipients of marginal cadaveric donor kidneys compared with other recipients and wait-listed transplant candidates. J Am Soc Nephrol 2001;12(3):589597.

14. Pessione F, Cohen S, Durand D, et al. Multivariate analysis of donor risk factors for graft survival in kidney transplantation. Transplantation 2003;75(3):361-367

15. Phongsamran PV. Critical care pharmacy in donor management. Prog Transplant. 2004;14(2):105-111

16. Rao PS, Schaubel DE. Guidinger, et al. A comprehensive risk quantification score for deceased donor kidneys: the kidneydonor risk index. Transplantation 2009; 88(2):231-236

17. Remuzzi G, Grinyo J, Ruggenenti P, et al. Early experience with dual kidney transplantation in adults using expanded donor criteria. Double Kidney Transplant Group (DKG). J Am Soc Nephrol. 1999;10(12):25912598

18. Sánchez-Fructuoso A, Naranjo Garcia P, Calvo Romero N, et al. Effect of the brain-death process on acute rejection in renal transplantation. Transplant Proc. 2007;39(7):2214-2216

19. Schnuelle P, Yard BA, Braun C, et al. Impact of donor dopamine on immediate graft function after kidney transplantation. Am J Transplant. 2004;4(3):419-426

20. Schold JD, Kaplan B. Baliga RS, Meier-Kriesche HU. The broad spectrum of quality in deceased donor kidneys. American Journal of Transplantation, 2005;5(4):757-765

21. Schwarz C, Regele H, Steininger R, Hansmann C, Mayer G, Oberbauer R. The contribution of adhesion molecule expression in donor kidney biopsies to early allograft dysfunction. Transplantation. 2001;71(11):1666-1670.

22. Skinner DL, Hardcastle TC, Rodseth RN, Muckart DJ. The incidence and outcomes of acute kidney injury amongst patients admitted to a level I trauma unit. Injury $2014 ; 45(1): 259-264$

23. Su XM, Zenios SA, Chertow GM. Incorporating recipient choice in kidney transplantation. J Am Soc Nephrol 2004; 15(6):1656 - 1663

24. Ugarte R, Kraus E, Montgomery RA, et al. Excellent outcomes after transplantation of deceased donor kidneys with high terminal creatinine and mild pathologic lesions. Transplantation 2005; 80(6):794-800.

25. van der Hoeven JA, Molema G, Ter Horst GJ, et al. Relationship between duration of brain death and hemodynamic (in)stability on progressive dysfunction and increased immunologic activation of donor kidneys. Kidney Int. 2003;64(5):1874-1882. 